\title{
Combined Effect of Water Deficit and Salt Stress on the Structure of Mesophyll Cells in Wheat Seedlings
}

\author{
Galina Semenova ${ }^{1 *}$, Irina Fomina ${ }^{2,3}$, Anatoly Ivanov ${ }^{2}$ \\ ${ }^{1}$ Institute of Theoretical and Experimental Biophysics, Russian Academy of Sciences, Pushchino, Russia \\ ${ }^{2}$ Institute of Basic Biological Problems, Russian Academy of Sciences, Pushchino, Russia \\ ${ }^{3}$ Biosphere Systems International Foundation, Tucson, USA \\ Email: ${ }^{\text {irafomi@rambler.ru }}$
}

Received 9 January 2014; revised 9 February 2014; accepted 17 February 2014

Copyright (C) 2014 by authors and Scientific Research Publishing Inc.

This work is licensed under the Creative Commons Attribution International License (CC BY). http://creativecommons.org/licenses/by/4.0/

c) (i) Open Access

\section{Abstract}

The purpose of the work was to assess the combined effect of drought and salinity $(50,100,200$ $\mathrm{mM} \mathrm{NaCl)}$ on the meso- and ultrastructure of mesophyll cells of wheat seedlings. Stress development was estimated by a decrease in the relative water content (RWC) and $\mathrm{CO}_{2}$-dependent $\mathrm{O}_{2}$ evolution $\left(A_{n}\right)$ in leaves. The decrease in the RWC and in $A_{n}$ occurred rapidly in the absence of salt in the substrate and slowly in the presence of salt, especially at a treatment of $100 \mathrm{mM} \mathrm{NaCl}$. The resumption of watering led to the recovery of the both parameters in all variants except one with $200 \mathrm{mM} \mathrm{NaCl}$. Structural studies showed that a weak drought stress (RWC 60\%) without salinity led to the destruction of cell membranes and hyaloplasm, which did not occur in all salt treatments. By contrast, the ultrastructure of nuclei in weak drought without salinity remained unchanged, whereas in all salt treatments chromatin changed substantially. Heterochromatin underwent a strong condensation followed by the fusion into a united mass with the simultaneous loss of electron density. A strong water stress (RWC 40\%) in all variants led to cell destruction and the hydrolysis of cell compounds. Under the drought without salinity, vacuoles disappeared, whereas in salt-treated samples they were retained and filled with organelles being at different degrees of degradation. Cell nuclei under strong drought stress lost their rounded shape, nuclear envelopes were destroyed, and at the end only a finely dispersed substance remained. Thus, under the combined action of drought and salt, there is some critical level of salt concentration in substrate above which the effect of $\mathrm{NaCl}$ changes to the adverse, which enhances the action of drought. Among structural components of mesophyll cells, the most sensitive parts to $\mathrm{NaCl}$ are nuclei and their chromatin.

"Corresponding author. 


\section{Keywords}

\section{Chromatin; Meso- and Ultrastructure of Mesophyll; Salt and Water Stress; Triticum aestivum}

\section{Introduction}

Abiotic stressors, such as drought and salinization, are serious threats to agriculture and the natural status of the environment. Plant responses to salt and drought separately are closely related to the mechanisms' overlap [1]. Combined effect of drought and salt on photosynthetic characteristics of spring wheat has been studied recently [2]. Both drought and salinization lead to the development of osmotic stress [1] and oxidative stress in plant tissues [3]. Reactive oxygen species (ROS) damages membranes, proteins and DNA [3]. The physiological status of stressed plants is usually assessed by the suppression of photosynthesis [4]. The dehydration is prevented in plants by the activation of mechanisms, such as stomata closure, structural transformation of tissues and decrease in osmotic potential of cells by the accumulation of osmotically active substances, which maintain the balance of absorption and loss of water [5].

Structural studies concerned with the effects of water or salt stress on mesophyll cells were performed mainly on chloroplasts [6]-[12]. There are very few works that consider the response of other cell components to dehydration and salinity [13]-[16]. The combined effect of these stress factors on the meso- and ultrastructure of plants has not been properly investigated.

We suppose that the salt concentration in the substrate above a certain critical level increases the effects of drought, and the nucleus and chromatin are most sensitive to $\mathrm{NaCl}$ of the structural components of mesophyll cells. The goal of this work was to examine the responses of mesophyll cell structures to water deficit and salt stress in leaves of wheat seedlings.

\section{Materials and Methods}

\subsection{Plant Cultivation}

Wheat (Triticum aestivum L.) cv. Moskovskaya 35 was grown in a controlled climate chamber (Russia) in $0.5 \mathrm{~L}$ vessels (100 plants per vessel) as described [17] [18]. The light intensity was measured with a quantum meter (LI-250 QSX-01, Li-Cor Inc., Lincoln, NE, USA) and was $690 \mu \mathrm{E} \mathrm{m}^{-2} \cdot \mathrm{s}^{-1}$. The substrate was sand washed from soluble impurities. The growing temperature was $20^{\circ} \mathrm{C} / 17^{\circ} \mathrm{C}$ (day/night) with a $12 \mathrm{~h}$ photoperiod and a relative humidity of $65 \% \pm 5 \%$. Plants were watered with distilled water up to the full saturation of the substrate. The nutrient solution was not supplied to the seedlings. Control seedlings showed a stable level of photosynthesis and growth rate for 20 days of experiment. The relative water content (RWC) in the substrate was calculated as the percent of the moisture capacity of this substrate.

Ten days after seedling emergence, when the plants reached the phase of the appearance of two leaves, 50 $\mathrm{mM} \mathrm{NaCl}$ salt solution was used for irrigation twice daily until final concentrations of 50, 100, and $200 \mathrm{mM}$ were reached in the vessels ( 3 vessels per treatment). After this, watering was terminated in half of non-treated and in all salt-treated variants. The variant without $\mathrm{NaCl}$ and with watering served as a control. Experiments were carried out for several days with a gradual decrease in RWC in the substrate and leaves. The watering was resumed after leaf RWC reached 40\% (see Figure 1(a)).

Second leaves of plants were used for investigations.

\subsection{Relative Water Content in Leaves}

The RWC in separated leaves (20-mm fragments) was determined from the ratio of fresh (FW) and dry weight (DW) by the equation: RWC $=100(\mathrm{FW}-\mathrm{DW}) /(\mathrm{TW}-\mathrm{DW})$, where TW (turgid weight) is the FW of leaves on complete water saturation [19].

\section{3. $\mathrm{CO}_{2}$-Dependent $\mathrm{O}_{2}$ Evolution}

The rate of light-saturated $\mathrm{CO}_{2}$-dependent $\mathrm{O}_{2}$ exchange by leaf slices suspended in a 5-ml temperature-con- 

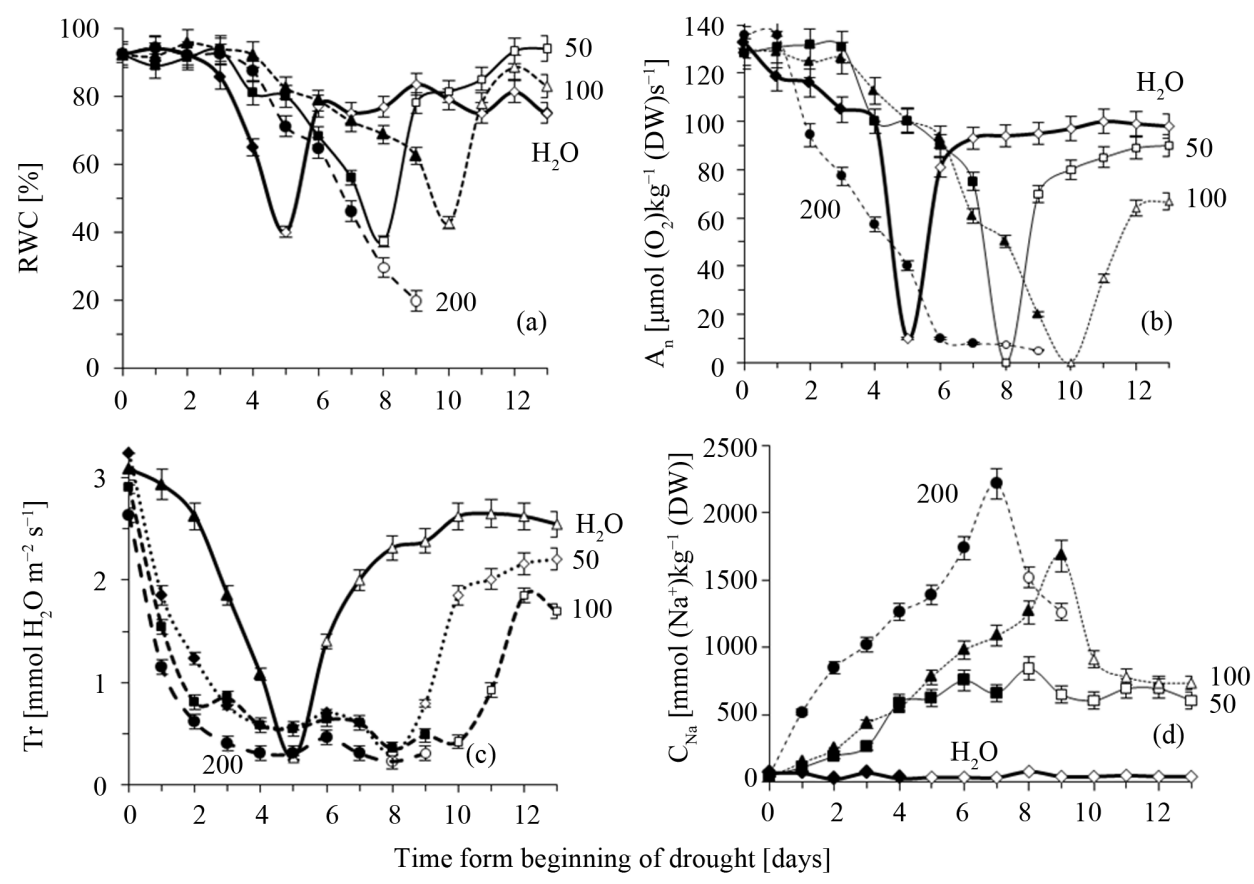

Figure 1. RWC in second leaves (a); net evolution of $\mathrm{O}_{2}, \mathrm{~A}_{n}$ (b); transpiration, $\operatorname{Tr}$ (c); and concentration of $\mathrm{Na}^{+}$in the leaf blades, $\mathrm{C}_{\mathrm{Na}}(\mathrm{d})$ of wheat seedlings during drought development in the absence $\left(\mathrm{H}_{2} \mathrm{O}\right)$ and with the presence of $\mathrm{NaCl}$ (treatments are indicated by indexes near the curves) in substrate. The resumption of watering after each treatment is denoted by white-icons; (means \pm $\mathrm{SD} ; n=5)$.

trolled cell $\left(28^{\circ} \mathrm{C}\right)$ with $50 \mathrm{mM} \mathrm{K-phosphate} \mathrm{buffer} \mathrm{(pH} \mathrm{7.5)} \mathrm{was} \mathrm{determined} \mathrm{using} \mathrm{a} \mathrm{polarograph} \mathrm{(LP} \mathrm{7E,} \mathrm{Labo-}$ ratorni Prristoje, Praha, Czech Republic) with a standard platinum Clark electrode at a light intensity of $1200 \mu \mathrm{E}$ $\mathrm{m}^{-2} \cdot \mathrm{s}^{-1}$ [20]. Before the beginning of measurements, the buffer solution in the cell was supplemented with an excess of sodium bicarbonate $(10 \mathrm{mM} \mathrm{NaHCO}$ ) sufficient to provide photosynthesis with a source of carbon. The net evolution of $\mathrm{O}_{2}, \mathrm{~A}_{\mathrm{n}}$, was calculated taking dark respiration after a 15-min incubation of samples in the dark into consideration.

\subsection{Transpiration Rate}

The rate of transpiration was estimated by decrease in FW of separated leaves during 5 min; measurements were made at $11-12 \mathrm{~h}$ am.

\section{5. $\mathrm{Na}^{+}$Concentration}

Concentration of $\mathrm{Na}^{+}$in the blade of the second leaf was measured according to [21]. Leaves were dried at $70^{\circ} \mathrm{C}$ for $3 \mathrm{~d}$, extracted in $500 \mathrm{mM} \mathrm{HNO}_{3}$ at $80^{\circ} \mathrm{C}$ for $1.5 \mathrm{~h}$, and $\mathrm{Na}^{+}$concentration was measured using a flame photometer (BWB-XP Performance Plus, BWB Technologies, UK).

\subsection{Optical and Electron Microscopy}

For the optical and electron microscopy, small segments of fully expanded leaves were fixed in $2.5 \%$ glutaraldehyde in $0.1 \mathrm{M}$ phosphate buffer (pH 7.2) for $3 \mathrm{~h}$, as described earlier [22]. The samples were then postfixed in $1 \% \mathrm{OsO}_{4}$, dehydrated in a graded ethanol and acetone series, and embedded in Epon-812. Sections for the optical microscopy ( $2-3 \mu \mathrm{m}$ ) were not stained; they were examined under a transmitted-light microscope (Axiostar Plus, Carl Zeiss, Göttingen, Germany) and photographed by a digital camera. Sections for the electron microscopy stained with uranyl acetate followed by lead citrate were examined under an electron microscope (JEM 100B, Jeol, Tokyo, Japan). 


\subsection{Data, Replication, Statistics}

The measurements of RWC, $\mathrm{O}_{2}$ evolution of leaves, and other parameters were made in five biological replications. The data are presented as the means and SD (bars). For electron microscopy studying from two to three hundreds of nucleus-containing mesophyll cells were examined in each variant.

\section{Results}

The dynamics of changes in the RWC of the substrate after the termination of watering indicates that, in salt treatments, the substrate lost water slower than in drought in the absence of salt (Table 1).

The decrease in the RWC of leaves to $60 \%$ (weak stress) occurred over a period of 6 days at 50 - and 200-mM $\mathrm{NaCl}$ treatments and over a period of 9 days at $100-\mathrm{mM} \mathrm{NaCl}$ treatment (Figure $1(\mathrm{a})$ ). The decrease in the RWC of leaves to $40 \%$ (strong stress) occurred over a period of 8 days at 50 - and $200-\mathrm{mM} \mathrm{NaCl}$ treatments and over a period of 10 days at $100-\mathrm{mM} \mathrm{NaCl}$ treatment. The RWC of leaf tissues in the absence of salt in substrate decreased more rapidly than in treatments with salt: to $60 \%$ for 4 days and to $40 \%$ for 5 days. The resumption of watering led to an increase in the RWC of leaves in all treatments except one with $200 \mathrm{mM} \mathrm{NaCl}$ (Figure 1(a)).

During the development of drought, the decrease in RWC of leaves to $60 \%$ was accompanied by the suppression of the net evolution of $\mathrm{O}_{2}\left(\mathrm{~A}_{\mathrm{n}}\right)$. The suppression was most rapid in the absence of salt in substrate and slowest in the case of $100 \mathrm{mM} \mathrm{NaCl}$. Further decrease in RWC of leaves to $40 \%$ (strong stress) corresponded to the complete termination of $A_{n}$ in all treatments (Figure 1(b)). The resumption of watering led to the recovery of $A_{n}$ in all treatments except one with $200 \mathrm{mM} \mathrm{NaCl}$ (Figure 1(b)). The rate of transpiration decreased rapidly in salt treated plants; its increase after resumption of watering was similar to increase in photosynthetic capacities in each treatment (Figure 1(c)). Increase in $\mathrm{Na}^{+}$concentration in leaves of salt treated plants was the biggest in 200-mM treatment, up to $2220 \mathrm{mmol} \mathrm{Na}^{+}$per kg DW. In 100- and 50-mM treated plants it reached 1700 and $750 \mathrm{mmol} \mathrm{Na}{ }^{+}$per kg DW, respectively. Then $\mathrm{Na}^{+}$concentration in leaf displayed decrease that continued with resumption of watering and was significant in 100- and 200-mM treated plants but was not significant in 50-mM treated plants (Figure $1(\mathrm{~d})$ ).

\subsection{Optical Microscopy}

Figure 2(a) shows a cross section of a wheat leaf of a control plant before the termination of watering. Epidermal cells are rounded, the vacuole in mesophyll cells is clearly defined, and chloroplasts are localized in the parietal layer of the cytoplasm.

\begin{tabular}{ccccc} 
Table 1. Relative water content in substrate, \%. \\
\hline \multirow{4}{*}{ Time [days] } & \multicolumn{4}{c}{ Treatment } \\
\cline { 2 - 5 } & $\mathrm{H}_{2} \mathrm{O}$ & $50 \mathrm{mM} \mathrm{NaCl}$ & $100 \mathrm{mM} \mathrm{NaCl}$ & $200 \mathrm{mM} \mathrm{NaCl}$ \\
\hline 0 & 100 & 100 & 100 & 100 \\
1 & 60.4 & 65.4 & 70.9 & 80.1 \\
2 & 33.8 & 43.4 & 51.2 & 63.8 \\
3 & 16.4 & 25.6 & 35.2 & 50.2 \\
4 & 9.1 & 16.2 & 24.1 & 40.1 \\
5 & 5.8 & 10.3 & 18.5 & 32.4 \\
6 & & 7.1 & 13.1 & 24.6 \\
7 & & 6.4 & 9.3 & 20.5 \\
8 & & 5.3 & 6.4 & 18.6 \\
9 & & & 5.3 & \\
\hline 10 & & & 4.3 & \\
\hline
\end{tabular}




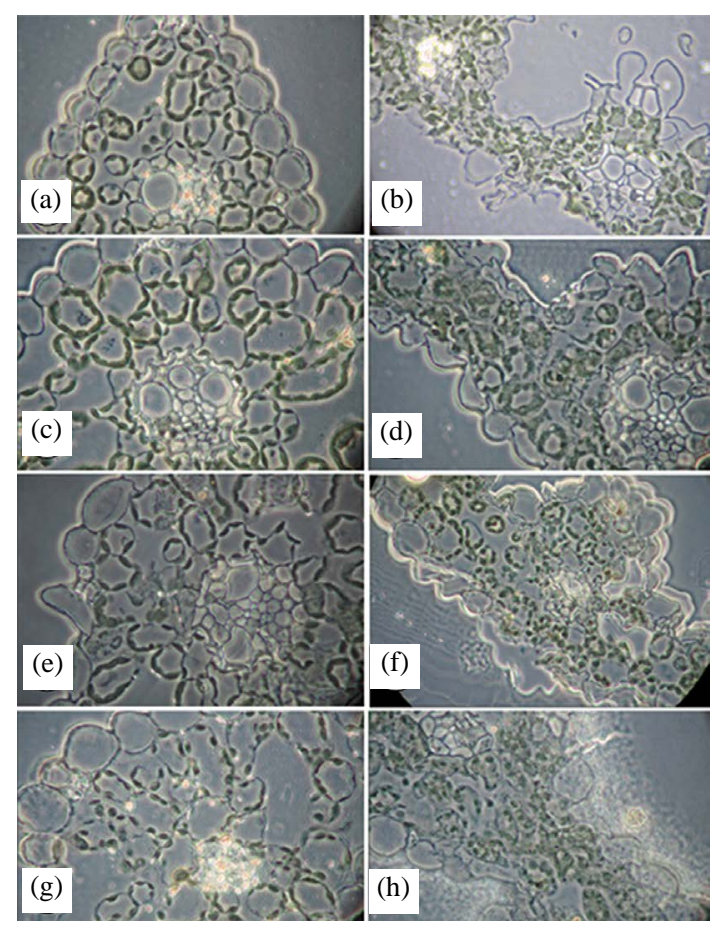

Figure 2. Mesostructure of cross-sections of the second leaf of wheat seedlings in (a) control plants grown with watering by distilled water, (b) in drought in the absence of salt in substrate for 5 days (RWC of leaves $40 \%)$, (c)-(h) in drought in the presence of salt: (c) $50 \mathrm{mM} \mathrm{NaCl}$ for 6 days (RWC of leaves 60\%), (d) $50 \mathrm{mM} \mathrm{NaCl}$ for 8 days (RWC of leaves 40\%), (e) 100 $\mathrm{mM} \mathrm{NaCl}$ for 9 days (RWC of leaves $60 \%$ ), (f) 100 $\mathrm{mM} \mathrm{NaCl}$ for 10 days (RWC of leaves 40\%), (g) 200 $\mathrm{mM} \mathrm{NaCl}$ for 6 days (RWC of leaves 60\%), (h) 200 $\mathrm{mM} \mathrm{NaCl}$ for 8 days (RWC of leaves $40 \%$ ). Objective $\times 100$.

In drought with the RWC of leaves $60 \%$ (weak stress), the leaf structure remained unchanged (data not shown). Decreasing the RWC of leaves to $40 \%$ (strong stress) led to marked changes in the leaf mesostructure (Figure 2(b)). Epidermal cells strongly flattened except cells adjacent to stomata. The thickness of the leaf in the region of interfascicular mesophyll became thinner about twice due to the loss of vacuoles (Figure 2(b)).

At $50-\mathrm{mM} \mathrm{NaCl}$ treatment in weak stress (RWC of leaves $60 \%$ ), the leaf mesostructure remained unchanged (Figure 2(c)) compared with the control (Figure 2(a)). Namely, epidermal cells were rounded, the vacuole in mesophyll cells was clearly defined, and chloroplasts were localized in the parietal layer of the cytoplasm. Strong stress (RWC of leaves $40 \%$ ) led to significant changes in the leaf mesostructure: the layer of interfascicular mesophyll became thinner, cells and vacuoles reduced in size, but to a lesser extent than in the experiment without salt, and epidermal cells were rather flattened (Figure 2(d)).

At 100 -mM salt treatment in weak stress, the leaf mesostructure also did not differ from the control (Figure 2(e)). In strong stress, the disturbances in the leaf structure were less dramatic than in experiments with the absence of salt. The epidermis did not flatten, and mesophyll cells and their vacuoles decreased in size to a lesser extent than in experiments without salt (Figure 2(f)).

At 200-mM salt treatment in weak stress, the leaf structure did not differ from the control (Figure 2(g)). In strong stress, the thickness of the leaf in the layer of interfascicular mesophyll decreased twofold due to a decrease in the sizes of vacuoles and cells (Figure 2(h)). Epidermal cells flattened, though not as strongly as in strong water stress without salt. The halo over the epidermis represents probably a deposit of salt of the leaf surface (Figure 2(h)). 


\subsection{Electron Microscopy}

Sections of leaves of control plants showed a typical structure of the mesophyll (Figure 3), which is represented by rounded cells with a large central vacuole. The narrow cytoplasmic strand restricted by cell membranes (tonoplast and plasmalemma) is localized near the wall and contains chloroplasts and mitochondria. Mitochondria in both the control and all experimental variants contained a low-density matrix and a small number of crysts. Chloroplasts had a well-developed system of thylakoids and a matrix of a moderate electron density. Chloroplasts of control plants contained one or two small granules of starch (Figure 3). In all experimental variants, starch granules were absent (see Figures 4 and 5 ).

In weak water stress, mesophyll cells remained rounded and retained the initial volume although cell membranes in most cells were either fragmented or absent at all. The hyaloplasma was degraded; however, chloroplasts and mitochondria remained intact (Figure 4(a)). In strong water stress, cell walls shrank to form folds (cytorysis). Cells decreased in volume, vacuoles were almost invisible, and the rest of the volume was occupied by chloroplasts, which retained both the matrix and the thylakoid system (Figure 4(b)).

In the presence of $50 \mathrm{mM} \mathrm{NaCl}$ in a weak stress, mesophyll cells remained rounded and had a well-defined vacuole. The plasmalemma and the tonoplast in most cells remained intact. The cytoplasmic strand was somewhat denser and narrower than in the control. The matrix and the thylakoid system of chloroplasts remained unimpaired (Figure 5(a)). In strong stress, cells lost the round shape, and the entire cell volume was filled with the debris of cell structures with different degree of degradation, including chloroplasts (Figure 5(b)).

In the presence of $100 \mathrm{mM} \mathrm{NaCl}$ in a weak stress, mesophyll cells remained rounded and had a well-defined vacuole; the cytoplasmic strand was localized near the membrane. The plasmalemma and the tonoplast in most cells retained integrity. The matrix and the thylakoid system of chloroplasts remained unimpaired (Figure 5(c)).

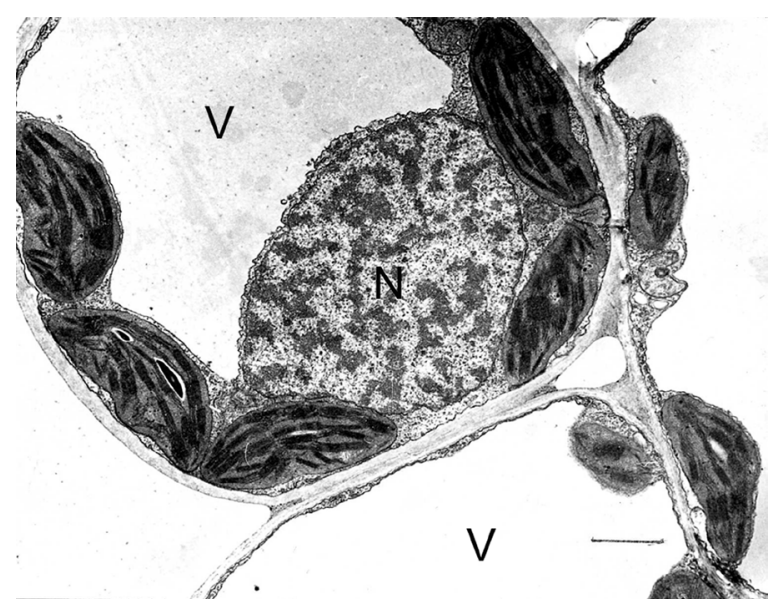

Figure 3. Ultrastructure of mesophyll cells of wheat seedlings grown with watering by distilled water (control). $\mathrm{N}-$ nucleus, $\mathrm{V}$-vacuole. Scale bar $=2 \mu \mathrm{m}$.

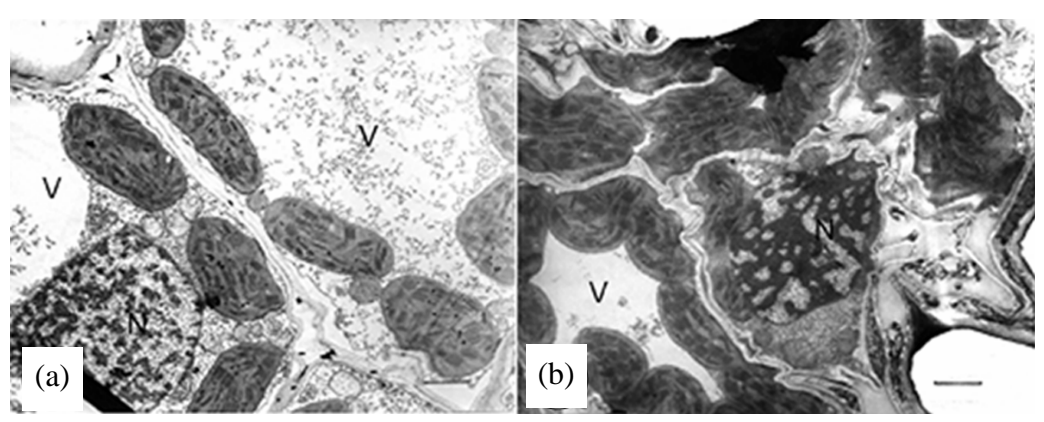

Figure 4. Ultrastructure of mesophyll cells of wheat seedlings grown at drought in the absence of salt in substrate (a) for 4 days (RWC of leaves 60\%), (b) for 5 days (RWC of leaves $40 \%$ ). $\mathrm{N}$-nucleus, $\mathrm{V}$-vacuole. Scale bars $=2 \mu \mathrm{m}$. 


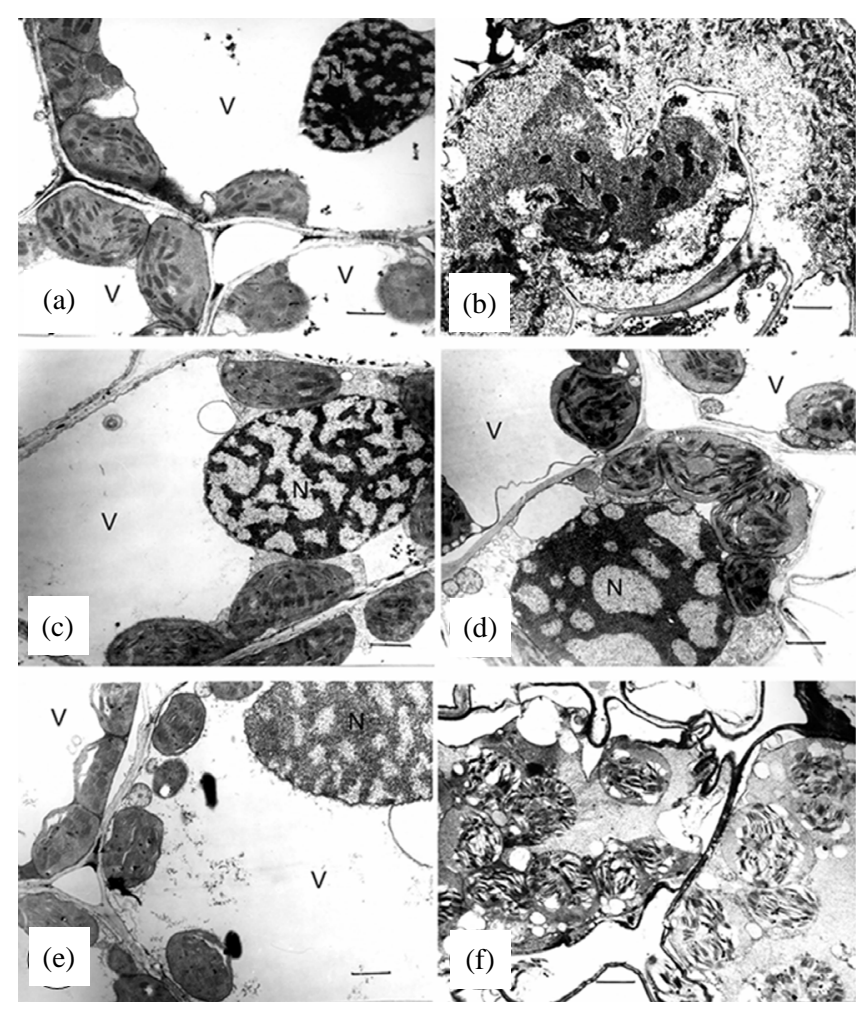

Figure 5. Ultrastructure of mesophyll cells of wheat seedlings grown at drought in the presence of salt in substrate (a) $50 \mathrm{mM}$ $\mathrm{NaCl}$ for 6 days (RWC of leaves $60 \%$ ), (b) $50 \mathrm{mM} \mathrm{NaCl}$ for 8 days (RWC of leaves 40\%), (c) $100 \mathrm{mM} \mathrm{NaCl}$ for 9 days (RWC of leaves $60 \%$ ), (d) $100 \mathrm{mM} \mathrm{NaCl}$ for 10 days (RWC of leaves $40 \%$ ), (e) $200 \mathrm{mM} \mathrm{NaCl}$ for 6 days (RWC of leaves $60 \%$ ), (f) $200 \mathrm{mM}$ $\mathrm{NaCl}$ for 8 days (RWC of leaves $40 \%$ ). $\mathrm{N}$-nucleus, $\mathrm{V}$-vacuole. Scale bars $=2 \mu \mathrm{m}$.

In strong stress, cells retained the round shape with a well-defined vacuole though cell membranes and the hyaloplasm were broken. Chloroplasts retained integrity and the parietal localization but became somewhat rounded; thylakoids partially swelled. The matrix and the thylakoid system of chloroplasts remained unimpaired (Figure $5(\mathrm{~d}))$.

At $200-\mathrm{mM} \mathrm{NaCl}$ treatment in a weak stress, mesophyll cells remained rounded but increased in size, due to the stretching of cell walls. In some cells, cell membranes and the hyaloplasm remained unbroken, but the plasmolysis occurred. Other cells lost cell membranes and the hyaloplasm. Chloroplasts remained intact, but thylakoids were partially swollen (Figure 5(e)). In strong stress, cells lost the round shape and stretched out. Cell membranes and the hyaloplasm were absent. The cell volume was filled with a finely dispersed substance into which cell organelles of different degree of degradation were submerged (Figure 5(f)).

In all cases of exposure to stressful factors, chloroplasts and mitochondria appeared to be the most resistant cell organelles. One of the most sensitive organelles was the nucleus.

In nuclei of mesophyll cells of control plants, heterochromatin was distributed comparatively uniformly (Figure 3). A similar situation occurred in weak stress (Figure 4(a)). In all variants in the presence of salt, even in weak stress, either a high degree of chromatin condensation (Figure 5(a)) or the coalescence of chromatin into a single mass with a simultaneous decrease in its electron density was observed (Figures 5(c) and (e)).

In strong drought stress, heterochromatin occupied almost the entire volume of the nucleus; only small regions were occupied by the nucleoplasm (Figure 4(b)). In strong stress in the presence of $100 \mathrm{mM} \mathrm{NaCl}$, nuclei were severely altered but retained the integrity (Figure 5(d)); in a variant with $50 \mathrm{mM}$ salt, the destruction of nuclei occurred (Figure 5(b)). They lost the round shape flattened; the envelope was broken, and the contents of the nucleus were released in the form of finely dispersed substance into the cell cavity. In the variant with 200 
$\mathrm{mM}$ salt in strong stress, there were no nuclei in mesophyll cells at all, and the cell cavity was occupied by a finely dispersed substance, which resulted presumably from their degradation (Figure 5(f)).

Figure 6 shows the sections of nuclei of mesophyll cells of a control plant and a plant exposed to a $200 \mathrm{mM}$ salt stress in weak drought at high magnification. In the control plant, chromatin appears as discrete structured electron dense structures localized in a clear nucleoplasm (Figure 6(a)). Chromatin of the stressed nucleus represents a homogenous low-density mass, and the rest of the nucleoplasm is denser (Figure 6(b)).

\section{Discussion}

At present it is generally accepted that the main damaging factors at the cellular level in drought and salinity are the osmotic and toxic effects of salt [1]. Our experiments demonstrate that the supply of salt to the substrate leads to a more gradual depletion of substrate water (Table 1) and a slower decrease in RWC of leaves (Figure $1(a))$ and in their photosynthetic capacity (Figure 1(b)). This effect was more pronounced at $100-\mathrm{mM} \mathrm{NaCl}$ treatment compared with 50- and 200-mM NaCl treatment. It was shown earlier [18] and here (Figure 1(b)) that, under the progressing drought in the presence of $\mathrm{NaCl}$, the photosynthetic activity of wheat leaves decreased more slowly than in the absence of salt. However, if $200 \mathrm{mM} \mathrm{NaCl}$ was added to the substrate, the photosynthetic activity in leaves was not recovered after the resumption of watering. This salt treatment led to the dramatic increase in $\mathrm{Na}^{+}$concentration in the leaves (see Figure 1(d)) and to plant death.

The effect of the presence of $\mathrm{NaCl}$ in substrate under progressing drought was also shown for plants by structural studies. Namely, the decrease in the RWC of leaves to $60 \%$ (weak stress) did not change the leaf mesostructure in all treatments both in the presence and absence of salt in substrate (Figures 2(a), (c), (e) and (g)). Further decrease in the RWC to $40 \%$ (strong stress) led to dramatic changes in the leaf mesostructure in drought without salt in substrate (Figure 2(b)), whereas structural changes in the salt treatments were less pronounced (Figures 2(d), (f), and (h)). In weak water stress, the destruction of the plasmalemma, tonoplast, and hyaloplasm of mesophyll cells was not accompanied by the loss of the vacuolar space, while in strong water stress, a dramatic shrinking of cell walls and the complete disappearance of vacuoles occurred (see Figures 2(b), 4(a) and (b)). In drought with the presence of salt in substrate, the changes in chloroplast structure of mesophyll cells were in agreement with observations of other authors [11] [12]; cell walls and the vacuolar space changed little. Presumably, the damage of the barrier between the cell wall and the vacuole in water stress causes a rapid efflux of water. In the presence of salt, this efflux is hindered even during the cell membrane destruction (see Figures 2(f) and $5(\mathrm{~d})$ ).

In addition to these effects of salt treatments, our data indicate that $\mathrm{NaCl}$ adversely affects cell nuclei even in weak stress (Figures 5(a), (c) and (e)). In weak water stress without salt in substrate, the condensation of chromatin did not differ from that in the control plants, though the destruction of cell membranes occurred (see Figures 3 and 4(a)). At the same RWC of leaves in salt-exposed seedlings, significant changes in the chromatin struc-

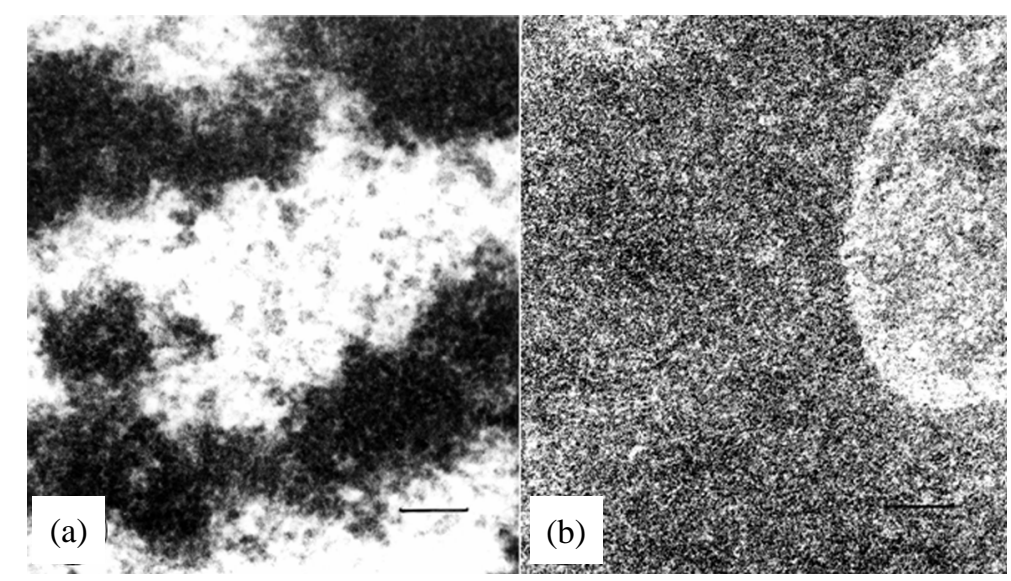

Figure 6. Ultrastructure of chromatin of the nucleus of mesophyll cells of wheat seedlings grown (a) with watering by distilled water (control) and (b) at drought in the presence of $200 \mathrm{mM} \mathrm{NaCl}$ in the substrate for 6 days (RWC of leaves $60 \%$ ). Scale bar $=0.2 \mu \mathrm{m}$. 
ture especially in the treatment with $200 \mathrm{mM} \mathrm{NaCl}$ were observed (see Figures 5(a), (c) and (e)). Under strong water stress, when the salt concentration in leaves increased (see Figure 1(d)), we observed the destruction (Figure 5(d)) and even the complete degradation of nuclei accompanied by the dissipation of chromatin (Figures $5(b)$ and (f)). We suppose that $\mathrm{Na}^{+}$distorts the discreteness of chromosomes in the interphase nucleus and leads to the fusion of chromatin into an integer mass.

It is well known that $\mathrm{Na}^{+}$produces a toxic effect on the vital activity of plant cells [23]-[26]. The concentration of $\mathrm{Na}^{+}$in substrate and in plant tissues may be different. In particular, the $\mathrm{Na}^{+}$concentration in the leaves of wheat grown for 10 days on the soil enriched with $50 \mathrm{mM} \mathrm{NaCl}$ was shown [27] to increase up to $250 \mathrm{mM}$. Other authors found that the content of $\mathrm{Na}^{+}$in leaves of the halophyte Suaeda is twice as high as in the soil solution [14] [28]. However, the targets exposed first to the salt attack are not clear. It was shown [29] that several histone modifications are dramatically altered on the stress-responsive gene region under drought, cold, and high salinity stress.

The treatment of isolated DNA with solutions of $\mathrm{NaCl}$, beginning from concentrations of $400 \mathrm{mM}$ and above, leads to the complete separation of DNA from histones [30]. In leaves of tomato cultivated under NaCl salinization, alkaline proteins, including histones, are affected to the greatest degree; the dissociation of histone complexes followed by their exit from the nucleus is assumed [23]. Growing barley on water solutions of $\mathrm{NaCl}$ at concentrations from 100 to $500 \mathrm{mM}$ resulted in the deformation and then the complete degradation of nuclei in root meristem cells, as indicated by optical microscopy data [31]. A biochemical analysis revealed the apoptosis-like DNA fragmentation; the addition of $10 \mathrm{mM} \mathrm{Ca}^{2+}$ to the nutrient medium abolished the adverse effect of $\mathrm{Na}^{+}[31]$.

There are very few ultrastructural data on the effect of salts on nuclear chromatin; these data were derived only for roots. In particular, a strong condensation of chromatin was noted in root cell nuclei in pea [23] and barley [32].

During the chromatin condensation, the nuclear DNA in wheat coleoptile cells undergoes an internucleosomal fragmentation [33]. A similar chromatin condensation is shown in Figure 5(a). A high content of the linker histone $\mathrm{H} 1$ in the chromatin of a transgenic tobacco causes the nanism and disturbance of flowering and is accompanied by a high density of heterochromatin in mesophyll nuclei [34]. In this case, all chromatin localized in the form of filaments in the nucleoplasm is converted to heterochromatin, and the nucleoplasm becomes electron transparent. A similar situation is observed in our study in the case of weak stress with $100 \mathrm{mM} \mathrm{NaCl}$ (Figure $5(\mathrm{c}))$.

We suppose that, in mesophyll cells, nuclear chromatin is one of the targets of the toxic effect of $\mathrm{NaCl}$. This is evident at the RWC of leaves of $40 \%$ in the presence of salt in the substrate when the complete degradation of nuclei occurs, which does not happen in the absence of salt (Figures 4(b), 5(b) and (f)). According to the observations of [35], the apoptotic internucleosomal fragmentation of DNA is accompanied by an increase in the nuclease activity. Based on our data, it is clear that chromatin exposed to salt at strong dehydration of cells undergoes radical structural rearrangements. The best retention of cell structures and the least degradation of nuclei in drought were observed at 100-mM NaCl treatment (Figures 5(c) and (d)).

\section{Conclusions}

Thus, under the combined action of drought and salt stresses, there is some critical level of salt concentration in substrate above which the effect of $\mathrm{NaCl}$ changes to the adverse, which enhances the action of drought.

Among structural components of mesophyll cells, the most sensitive parts to $\mathrm{NaCl}$ are nuclei and their chromatin.

\section{Acknowledgements}

We thank A.V. Shatilovich for her help in photographing in optical microscopy.

\section{References}

[1] Zhu, J.-K. (2002) Salt and Drought Stress Signal Transduction in Plants. Annual Review of Plant Biology, 53, $247-73$. http://dx.doi.org/10.1146/annurev.arplant.53.091401.143329

[2] Shadchina, T. (2004) Effect of Combined Stress Caused by Drought and Soil Salinity on Photosynthesis and Fluorescence Induction Parameters in Leaves of Spring Wheat. Acta Physiologiae Plantarum A, 26, 290-291.

[3] Stepien, P. and Klobus, G. (2005) Antioxidant Defense in the Leaves of C3 and C4 Plants under Salinity Stress. Physi- 
ologia Plantarum, 125, 31-40. http://dx.doi.org/10.1111/j.1399-3054.2005.00534.x

[4] Stepien, P. and Klobus, G. (2006) Water Relations and Photosynthesis in Cucumis sativus L. Leaves under Salt Stress. Biologia Plantarum, 50, 610-616. http://dx.doi.org/10.1007/s10535-006-0096-Z

[5] Verslues, P.E., Agarwal, M., Katiyar-Agarwal, S., Zhu, J. and Zhu, J.-K. (2006) Methods and Concepts in Quantifying Resistance to Drought, Salt and Freezing, Abiotic Stresses That Affect Plant Water Status. Plant Journal, 45, 523-539. http://dx.doi.org/10.1111/j.1365-313X.2005.02593.x

[6] Giles, K.L., Beardsell, M.F. and Cohen, D. (1974) Cellular and Ultrastructural Changes in Mesophyll and Bundle Sheath Cells of Maize in Response to Water Stress. Plant Physiology, 54, 208-212. http://dx.doi.org/10.1104/pp.54.2.208

[7] Giles, K.L., Cohen, D. and Beardsell, M.F. (1976) Effect of Water Stress on the Ultrastructure of Leaf Cells of Sorghum bicolor. Plant Physiology, 57, 11-14. http://dx.doi.org/10.1104/pp.57.1.11

[8] Freeman, T.P. and Duysen, M.E. (1975) The Effect of Imposed Water Stress on the Development and Ultrastructure of Wheat Chloroplasts. Protoplasma, 83, 131-145. http://dx.doi.org/10.1007/BF01289336

[9] Mittelheuser, C.J. (1977) Rapid Utrastructural Recovery of Water Stressed Leaf Tissue. Z.Pflanzenphysiologie, 82, 458-461.

[10] Maroti, I., Tuba, Z. and Csik, M. (1984) Changes of Chloroplast Ultrastructure and Carbohydrate Level in Festuca, Achillea and Sedum during Drought and After Recovery. Journal of Plant Physiology, 116, 1-10. http://dx.doi.org/10.1016/S0176-1617(84)80078-4

[11] Geissler, N., Hussin, S. and Koyro, H.-W. (2009) Elevated Atmospheric $\mathrm{CO}_{2}$ Concentration Ameliorates Effects of $\mathrm{NaCl}$ Salinity on Photosynthesis and Leaf Structure of Aster tripolium L. Journal of Experimental Botany, 60, 137-151. http://dx.doi.org/10.1093/jxb/ern271

[12] Naeem, M.S., Warusawitharana, H., Liu, H., Liu, D., Ahmad, R., Waraich, E.A., Xu, L. and Zhou, W. (2012) 5-Aminolevulenic Acid Alleviates the Salinity-Induced Changes in Brassica napus as Revealed by the Ultrastructural Study of Chloroplasts. Plant Physiology and Biochemistry, 57, 84-92. http://dx.doi.org/10.1016/j.plaphy.2012.05.018

[13] Berlin, J., Quisenberry, J.E., Bailey, F., Woodworth, M. and McMichael, B.L. (1982) Effect of Water Stress on Cotton Leaves. I. An Electron Microscopic Stereological Study of the Palisade Cells. Plant Physiology, 70, 238-243. http://dx.doi.org/10.1104/pp.70.1.238

[14] Kurkova, E.B. and Balnokin, Yu.V. (1994) Pinocytosis and Its Possible Role in Ion Transport in the Salt-Accumulating Organs of Halophytes. Russian Journal of Plant Physiology, 41, 507-511.

[15] Koyro, H.W. (1977) Ultrastructural and Physiological Changes in Root Cells of Sorghum Plants (Sorghum bicolor $\times$ S. sudanensis cv. Sweet Sioux) Induced by NaCl. Journal of Experimental Botany, 48, 693-706. http://dx.doi.org/10.1093/jxb/48.3.693

[16] Scippa, G.S., Michele, M.D., Onelli, E., Patrignani, G., Chiatante, D. and Bray, E.A. (2004) The Histone-Like Protein H1-S and the Response of Tomato Leaves to Water Deficit. Journal of Experimental Botany, 55, 99-109. http://dx.doi.org/10.1093/jxb/erh022

[17] Ivanov, A.A. (2010) Effect of Light Conditions of Wheat Growing on Sensitivity of Photosynthetic Machinery to Salt Stress. Russian Journal of Plant Physiology, 57, 770-777. http://dx.doi.org/10.1134/S102144371006004X

[18] Ivanov, A.A. (2010) Functional Changes of Photosynthetic Apparatus in Wheat Plants at Water Stress against the Background of NaCl. Agricultural Biology, 3, 88-93.

[19] Pardossi, A., Vernieri, P. and Tognoni, F. (1992) Involvement of Abscisic Acid in Regulating Water Status in Phaseolus vulgaris L. during Chilling. Plant Physiology, 100, 1243-1250. http://dx.doi.org/10.1104/pp.100.3.1243

[20] Bil, K.Ya., Fomina, I.R. and Tsenova, E.N. (1985) Effects of Nitrogen Nutrition on Photosynthetic Enzyme Activities, Type of Photosynthates and Photosystem 2 Activity in Maize Leaves. Photosynthetica, 19, 216-220.

[21] Munns, R., Hare, R.A., James, R.A. and Rebetzke, G.J. (2000) Genetic Variation for Improving the Salt Tolerance of Durum Wheat. Australian Journal of Agricultural Research, 51, 69-74. http://dx.doi.org/10.1071/AR99057

[22] Semenova, G. (2002) The Thylakoid Membrane in a Wide pH Range. Journal of Plant Physiology, 159, 613-625. http://dx.doi.org/10.1078/0176-1617-0632

[23] Stroganov, B.P., Kabanov, V.V. and Rakova, N.I. (1970) Features of Protein and Nucleic Acid Metabolism during Formative Changes in Plants under Salinization Conditions. Soviet Journal of Plant Physiology, 17, 394-401.

[24] Jennings, D.H. (1976) The Effects of Sodium Chloride on Higher Plants. Biological Reviews, 51, 453-486. http://dx.doi.org/10.1111/j.1469-185X.1976.tb01064.x

[25] Munns, R., James, R.A. and Läuchli, A. (2006) Approaches to Increasing the Salt Tolerance of Wheat and Other Cereals. Journal of Experimental Botany, 57, 1025-1043. http://dx.doi.org/10.1093/jxb/erj100 
[26] Munns, R. and Tester, M. (2008) Mechanisms of Salinity Tolerance. Annual Review of Plant Biology, 59, 651-681. http://dx.doi.org/10.1146/annurev.arplant.59.032607.092911

[27] Davenport, R., James, R.A., Zakrisson-Plogander, A., Tester, M. and Munns, R. (2005) Control of Sodium Transport in Durum Wheat. Plant Physiology, 137, 807-818. http://dx.doi.org/10.1104/pp.104.057307

[28] Orlova, Yu.V., Myasoedov, N.A., Kirichenko, E.B. and Balnokin, Yu.V. (2009) Contributions of Inorganic Ions, Soluble Carbohydrates, and Multiatomic Alcohols to Water Homeostasis in Artemisia lerchiana and A. pauciflora. Russian Journal of Plant Physiology, 56, 200-210. http://dx.doi.org/10.1134/S1021443709020083

[29] Kim, J.-M., To, T.K., Nishioka, T. and Seki, M. (2010) Chromatin Regulation Functions in Plant Abiotic Stress Responses. Plan, Cell and Environment, 33, 604-611. http://dx.doi.org/10.1111/j.1365-3040.2009.02076.X

[30] Ohlenbusch, H.H., Olivera, B.M., Tuan, D. and Davidson, N. (1967) Selective Dissociation of Histones from Calf Thymus Nucleoprotein. Journal of Molecular Biology, 25, 299-315. http://dx.doi.org/10.1016/0022-2836(67)90143-X

[31] Katsuhara, M. and Kawasaki, T. (1996) Salt Stress Induced Nuclear and DNA Degradation in Meristematic Cells of Barley Roots. Plant and Cell Physiology, 37, 169-173. http://dx.doi.org/10.1093/oxfordjournals.pcp.a028928

[32] Werker, E., Lerner, H.R., Weimberg, R. and Poljakoff-Mayber, A. (1983) Structural Changes Occurring in Nuclei of Barley Root Cells in Response to a Combined Effect of Salinity and Ageing. American Journal of Botany, 70, 222-225. http://dx.doi.org/10.2307/2443267

[33] Aleksandrushkina, N.I., Zamyatnina, V.A., Bakeeva, L.E., Seredina, A.V., Smirnova, E.G., Yaguzhinsky, L.S. and Vanyushin, B.F. (2004) Apoptosis in Wheat Seedlings Grown under Normal Daylight. Biochemistry—Moscow, 69, 285-294.

[34] Slusarczyk, J.S., Prymakowska-Bosak, M., Przewloka, M., Jerzmanowski, A. and Kuras, M. (1999) Ultrastructural Organization of Leaves of Transgenic Tobacco Overexpressing Histone H1 from Arabidopsis thaliana. Annual Botany, 84, 329-335. http://dx.doi.org/10.1006/anbo.1999.0925

[35] Aleksandrushkina, N.I., Seredina, A.V. and Vanyushin, B.F. (2009) Endonuclease Activities in the Coleoptile and the First Leaf of Developing Etiolated Wheat Seedlings. Russian Journal of Plant Physiology, 56, 154-163. http://dx.doi.org/10.1134/S1021443709020022 